\title{
SOLUBILITY AND MISCIBILITY OF REFRIGERANTS R407C AND R410A WITH SYNTHETIC COMPRESSOR OILS
}

In this paper, solubility and low temperature miscibility of refrigerants $R 407 C$ and $R 410 A$ in four different commercial Polyolester (POE) lubricants, produced by the same company but with different ISO standard viscosity grade, are measured with the aim to evaluate the possible correlation of solubility and miscibility with standard viscosity of the lubricant. Vapor pressure (solubility) is measured using calibrated, constant volume cells at oil mass fractions 30, 50, 70, 80, and 90\% over a temperature range from -20 to $100{ }^{\circ} \mathrm{C}$, and pressures up to $5 \mathrm{MPa}$. The measurements of low temperature miscibility limit (lower critical solution temperature LCST) were made using high-pressure sapphire cell. LCST was directly obtained by visual observation of a «milky haze» followed by a phase separation. Miscibility data were obtained at oil mass fractions from 5 to $50 \%$ over a temperature range from -60 to $0{ }^{\circ} \mathrm{C}$. A set of simple equations was derived to describe the experimental results. Analysis of the obtained results showed that the solubility of refrigerant/lubricant mixtures depends weakly on the viscosity grade of the oil. At the same time, the miscibility gap (LCST) differ much bigger for various refrigerant/lubricant mixtures. The lower viscosity grade of the oil, the lower LCST of the refrigerant/lubricant mixture. LCSTs for the mixtures of $\mathrm{R} 407 \mathrm{C}$ with the lubricants with the viscosity grades 32 and 220 differ by $30-45^{\circ} \mathrm{C}$.

Keywords: Solubility; Miscibility; Refrigerant; Polyolester Lubricant; Refrigerant/Lubricant Mixture; Measurements; Equation.

This work is licensed under the Creative Commons Attribution International License (CC BY). http://creativecommons.org/licenses/by/4.0/

\section{INTRODUCTION}

The transition to environmentally acceptable working fluids for refrigeration and air-conditioning systems requires the identification and optimal choice of new lubricants that are compatible with HFC refrigerants. The first requirement for such lubricants is that they are miscible with the refrigerants at all operating conditions. A miscible refrigerant/lubricant mixture is required in refrigeration systems for compressor lubrication, for maximum heat transfer performance in the evaporator, and for proper lubricant return to the compressor. Lubricant return is a continuous concern of manufacturers and operators, since it affects performance and reliability of the refrigeration system. Refrigerant/lubricant mixtures must have sufficient viscosities at high temperatures. For use is hermetic compressors with internal motors found in household refrigerators, such lubricants should also have good electrical insulation properties.

Polyol Ester (POE) lubricants have been identified to satisfy to these requirements for different types of refrigeration compressors. Commercial production of POEs and is currently available for ISO grade from 10 to 350. Almost all these lubricants have different additives that is affect greatly on the fluid properties (miscibility, solubility, density, and especially viscosity).

Unfortunately, there are no methods currently available for calculating properties that can provide reliable estimates for refrigerant/lubricant mixtures and optimal choice of lubricants for new refrigeration systems. Such methods for the solubility and miscibility may be based on the equation of state (EOS) and/or the activity-model (solution) theory, because the mutual solubility and miscibility are nothing but the thermodynamic phase equilibrium (vapor-liquid equilibrium VLE and vapor-liquid-liquid equilibrium VLLE). The models mentioned above must be verified by the reliable experimental data obtained for the mixtures of POEs with HFC alternative refrigerants, especially with mixed refrigerants $\mathrm{R} 407 \mathrm{C}$ and R410A. One of the potential problems in applying POEs in refrigerating machines is given by the possible immiscibility of the lubricant with the refrigerant. This phenomenon can determine oil accumulation inside the heat exchanger tubes, reducing heat transfer capabilities, and lowering the oil transportation to the compressor, resulting in an overall decrement of the refrigeration cycle performance and possible damages to the compressor.

The first objective of this work is to obtain an accurate body of data sufficient to characterize the solubility (VLE) and low temperature miscibility (lower critical solution temperature LCST) of refrigerants R407C and R410A with POE lubricants, produced by the same company but with different ISO standard viscosity. The second aim of this research is to evaluate the possible correlation of solubility and miscibility with standard viscosity of the lubricant.

\section{BRIEF LITERATURE REVIEW}

The fullest reviews of experimental data and the both predictive and correlative thermodynamic models for 
VLE of refrigerant/lubricant mixtures are given in the literature sources $[1,2]$. The main conclusions based on these reviews are the follows: (1) the most solubility data were obtained for the mixtures of the pure refrigerant (mainly R134a) with the POE lubricants by different producers, but it is impossible to systemize these results; (2) only limited information is available for the solubility of mixed refrigerants with the POE lubricants [1-5]; (3) miscibility limit at high temperatures (upper critical solution temperature UCST) and LCST until resent time practically were not studied. The exception are the work [6], where a limited experimental data were obtained for the UCST of the $\mathrm{CO}_{2}$ with the POE oils ISO 46 and ISO 68, and the research [7] for LCST of R134a with two samples of POE ISO 22.

The most reliable and detailed VLE and VLLE results were obtained for the mixtures of the blended refrigerant R410A and its compounds R32 and R125 with the POE oil ISO 32 [8]. A special visual experimental device was designed and the measurements were performed over a wide range of mixture compositions and a temperature range from -40 to $52{ }^{\circ} \mathrm{C}$. The results of this study show that immiscible area covers a wide range of parameters (for example, from 5 to $40 \%$ oil at $40{ }^{\circ} \mathrm{C}$ ).

\section{EXPERIMENTAL METHODS AND PROCEDURES}

Vapor pressure (solubility) measurements. A schematic diagram of the vapor pressure (solubility) measuring device is shown in Figure 1.

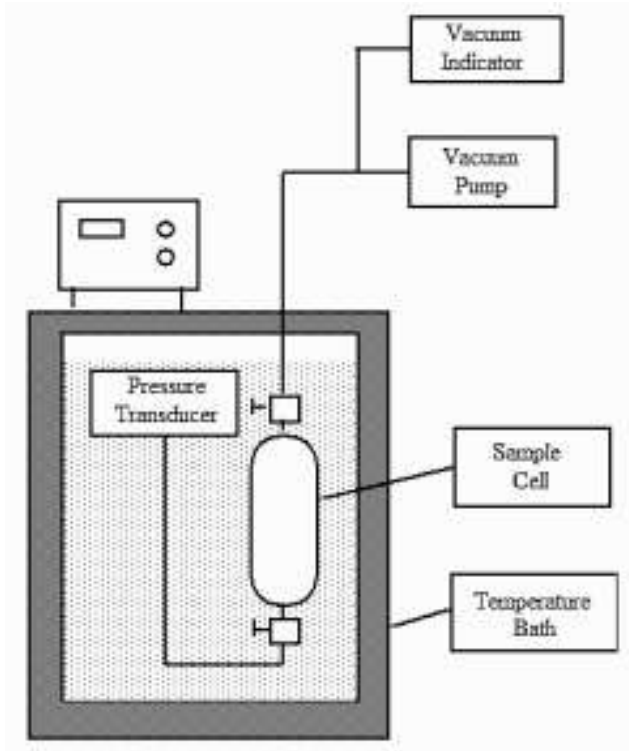

Figure 1 - Vapor pressure measuring device

Vapor pressure is measured using calibrated, constant volume cells with the volume of approximately $25 \mathrm{~cm}^{3}$, placed in the temperature bath and connected to the sensitive (to within $\pm 1 \mathrm{kPa}$ ) pressure transducer.

The design of this measuring device eliminated the condensation of the refrigerant in the line connected the cell and the pressure transducer. The mixture sample of a desired composition prepared by weighting each component is charged into the cell. The cell's head space is minimized, and the amount of vapor refrigerant in the head space at experimental temperature and pressure is calculated using the equations of states available from literature. Since the actual mixture composition in liquid phase changes with experimental temperature and pressure, the final mixture composition is determined taking into account the amount of vapor refrigerant in the head space. Vapor pressure data are obtained at essentially constant mixture composition over a range of temperatures by adjusting the amount of the lubricant and the refrigerant charged to the cell at each composition.

Miscibility measurements. LCST of the refrigerant/lubricant mixtures were measured to within experimental uncertainties that do not exceed $\pm 1{ }^{\circ} \mathrm{C}$ using the constant volume cell. A schematic diagram of this device is shown in Figure 2. The measurements were made using high pressure sapphire cell. The volume of the cell was calibrated with distilled water. The mixture sample of a desired composition was prepared by weighting each component and then was charged into the cell.

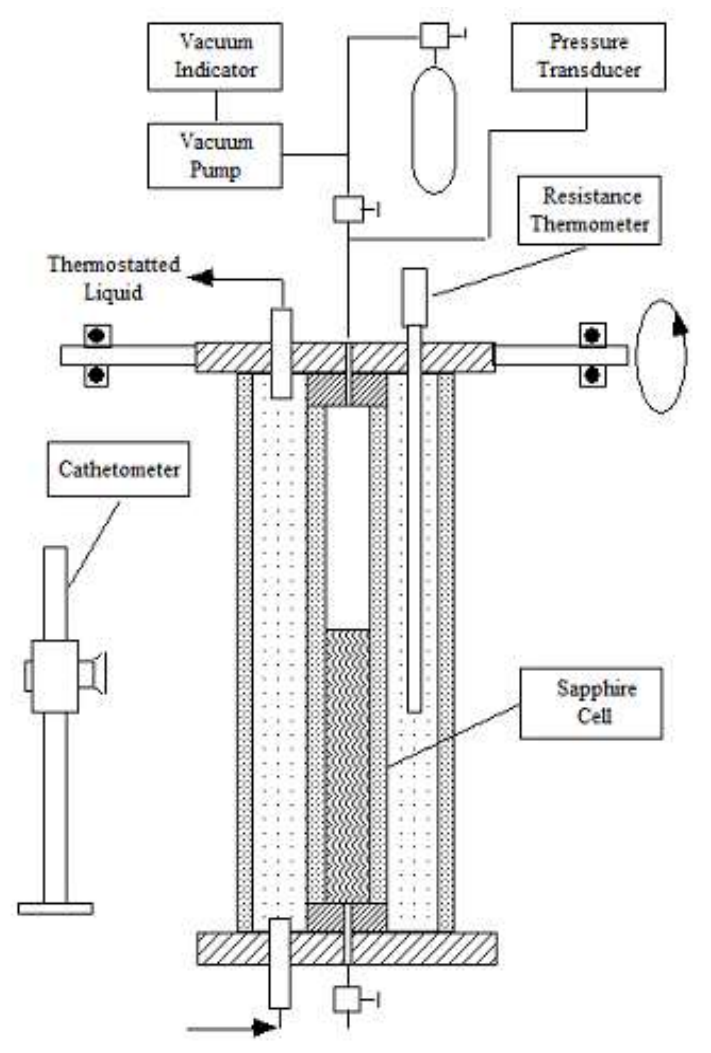

Figure 2-Miscibility measuring device

Miscibility limit (LCST) was directly obtained by visual observation of a «milky haze» followed by a phase separation. Assuming that the head space contains only the refrigerant blend in the vapor phase, we have analyzed the following affects: (1) the mass of the gaseous refrigerant blend changes with the level of the liquid, the temperature, and the pressure; (2) because of this, the 
concentration of the liquid phase changes too and may differ from the initial concentration; (3) the preferential solubility of the refrigerants may also change the initial mixture composition. Our calculations for the experimental conditions show that all these uncertainties are negligible.

\section{EXPERIMENTAL RESULTS AND DISCUSSION}

Vapor pressure and LCST were measured for 8 refrigerant/lubricant mixtures. Refrigerants $\mathrm{R} 407 \mathrm{C}$ and R410A and 4 POE lubricants ISO 32, 46, 68, and 220 by the same producer were chosen for this study. All solubility measurements are made at oil mass fractions $30,50,70,80$, and $90 \%$ over a temperature range from 20 to $100{ }^{\circ} \mathrm{C}$, and pressures up to $5 \mathrm{MPa}$. Figures 3 and 4 show vapor pressure - temperature and vapor pressure composition diagrams for R407C/POE 32 ludricant.

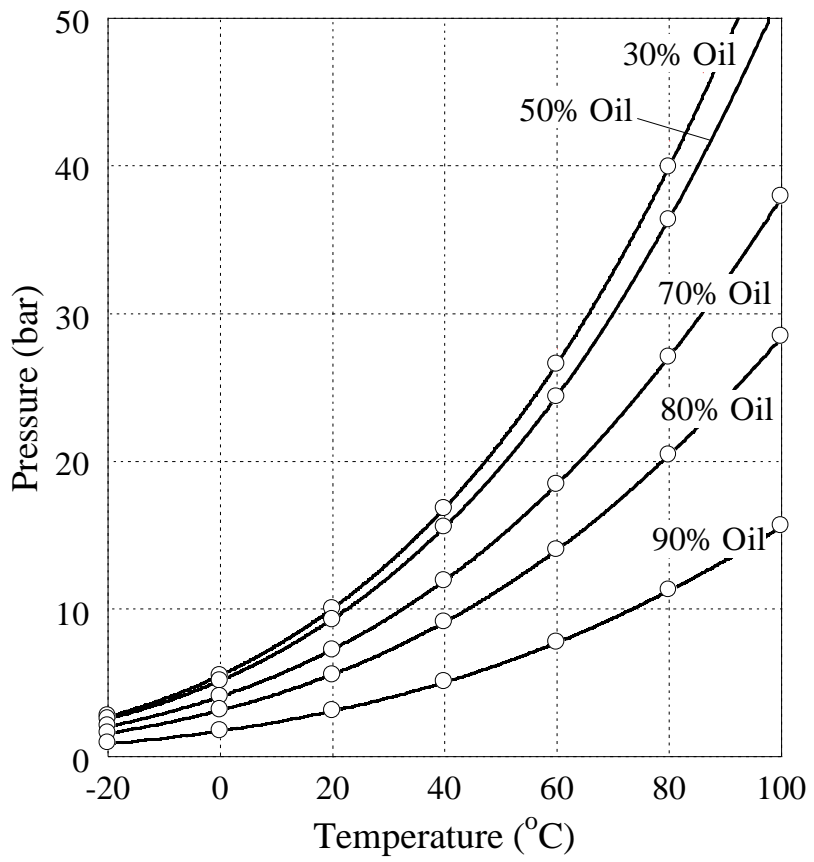

Figure 3 - Vapor pressure - temperature diagram for R407C/POE 32 lubricant

The following model has been applied to calculate the vapor pressure with uncertainties to within $\pm 2-3 \mathrm{kPa}$

$$
P=\sum_{i=0}^{3} \sum_{j=0}^{2} a_{i j} t^{i} x^{j}
$$

where $P$ is the pressure in bars, $t$ is the temperature in ${ }^{\circ} \mathrm{C}, x$ is the oil mass fraction.

The coefficients $a_{\mathrm{ij}}$ for all mixtures studied are given in Table 1 .

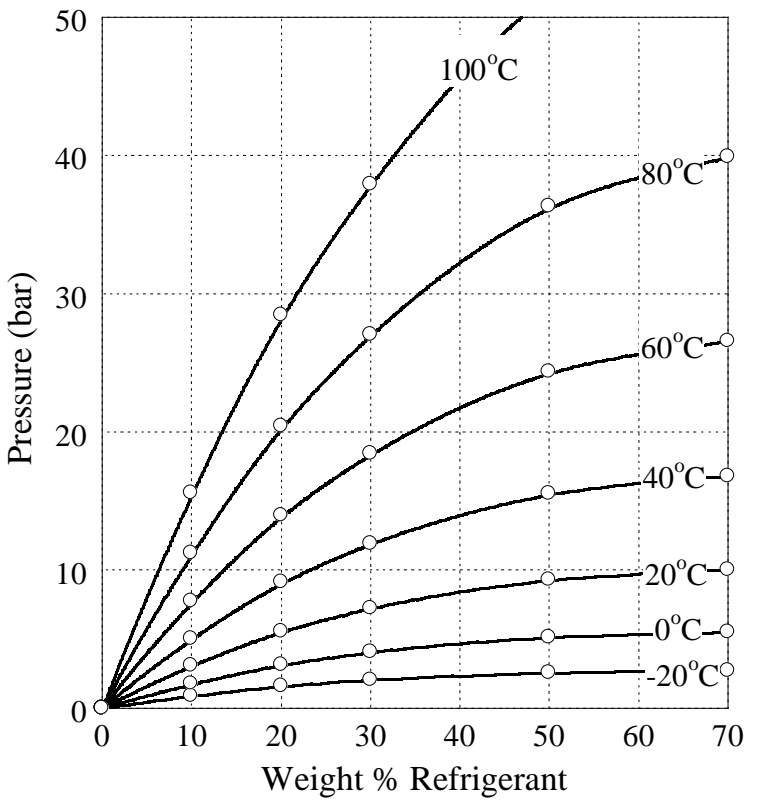

Figure 4 - Pressure - composition diagram for R407C/POE 32 lubricant.

Experimental LCST data are given in Table 2, and Figures 5 and 6 demonstrate the LCST for all systems under research.

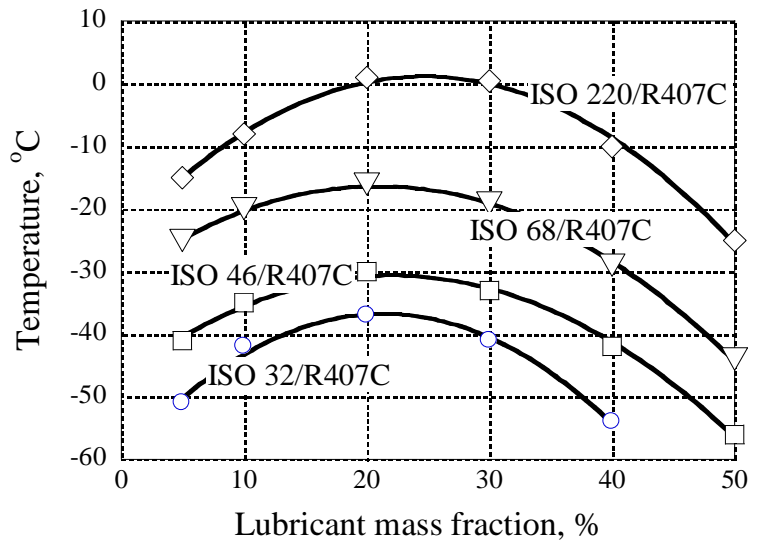

Figure 5 - LCST for R407C with different oils

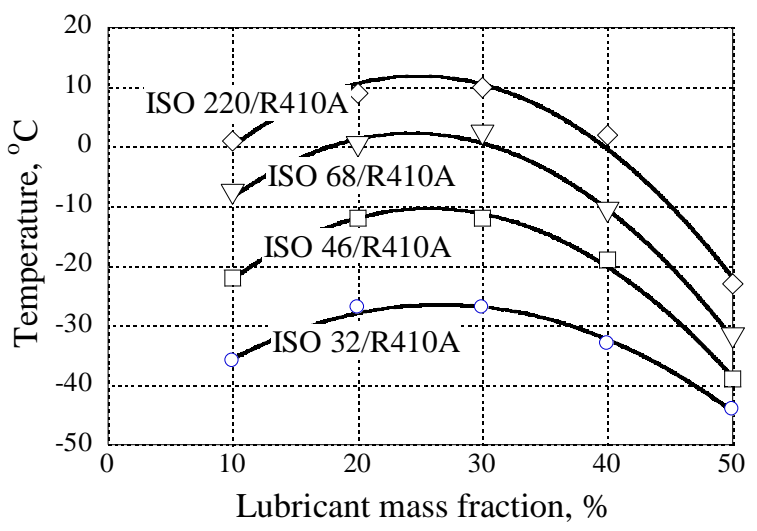

Figure 6 - LCST for R410A with different oils 
Uncertainties in estimation of LCST were defined as $\pm 1^{\circ} \mathrm{C}$ because of hysteresis in the measurements when the temperature decreases below the saturation temperature at which a second liquid phase appears and the temperature increases above this curve.

The obtained LCST data were treated as a function of the oil mass fraction $x$

$$
t=\sum_{i=0}^{2} b_{i} x^{i}
$$

where $t$ is the temperature in ${ }^{\circ} \mathrm{C}$.

The coefficients $b_{\mathrm{i}}$ are given in Table 3 . The parameters of solubility critical points are given in Table 4.

Analysis of the obtained results showed that higher viscosity oils leads to poor solubility of the refrigerants, but the solubility of refrigerant/lubricant mixtures depends weakly on the viscosity grade of the oil. For example, experimental vapor pressure data at $20{ }^{\circ} \mathrm{C}$ for the mixtures of R407C with the lubricants ISO 32 and ISO 68 differ by only 0,1 bar. At the same time, the miscibility gap (LCST) differ much bigger. The lower viscosity grade of the oil, the lower LCST of the refrigerant/lubricant mixture. As can be seen from Fig. 5, the LCSTs for the mixtures of R407C with the lubricants with the viscosity grades 32 and 220 differ by $30-45^{\circ} \mathrm{C}$.

\section{CONCLUSIONS}

Solubility and low temperature miscibility of refrigerants $\mathrm{R} 407 \mathrm{C}$ and $\mathrm{R} 410 \mathrm{~A}$ in four different commercial POE lubricants, produced by the same company but with different ISO standard viscosity grade (32, 46, 68, and 220), are measured with the aim to evaluate the possible correlation of solubility and miscibility with standard viscosity of the lubricant.

Vapor pressure (solubility) is measured using calibrated, constant volume cells, placed in the temperature bath and connected to the sensitive (to within $\pm 1 \mathrm{kPa}$ ) pressure transducer. Data are obtained at essentially constant mixture composition The mixture sample of a desired composition prepared by weighting each component is charged into the cell. Vapor pressure is measured at oil mass fractions 30, 50, 70, 80, and 90\% over a temperature range from -20 to $100{ }^{\circ} \mathrm{C}$, and pressures up to $5 \mathrm{MPa}$.

The measurements of miscibility limit (lower critical solution temperature) were made using highpressure sapphire cell. LCST was directly obtained by visual observation of a «milky haze» followed by a phase separation. Miscibility data were obtained at oil mass fractions from 5 to $50 \%$ over a temperature range from 60 to $0{ }^{\circ} \mathrm{C}$. A set of simple equations was derived to describe the experimental results. The parameters of solubility critical points were calculated.

Analysis of the obtained results showed that the solubility of refrigerant/lubricant mixtures depends weakly on the viscosity grade of the oil. At the same time, the miscibility gap (LCST) differ much bigger for various refrigerant/lubricant mixtures. The lower viscosity grade of the oil, the lower LCST of the refrigerant/lubricant mixture. LCSTs for the mixtures of R407C with the lubricants with the viscosity grades 32 and 220 differ by $30-45^{\circ} \mathrm{C}$.

Table 1 - The coefficients of equation (1)

\begin{tabular}{|l|cccc|cccc|}
\hline \multirow{2}{*}{ Coefficients } & \multicolumn{4}{|c|}{ R407C } & \multicolumn{4}{c|}{ R410A } \\
\cline { 2 - 9 } & ISO 32 & ISO 46 & ISO 68 & ISO 220 & ISO 32 & ISO 46 & ISO 68 & ISO 220 \\
\hline$a_{00}$ & 0,3979 & 0,3581 & 0,3857 & 0,3029 & 0,5430 & 0,5317 & 0,5307 & 0,5643 \\
$a_{01}$ & 0,8607 & 1,045 & 0,9180 & 1,290 & 1,274 & 1,331 & 1,352 & 1,180 \\
$a_{02}$ & $-1,222$ & $-1,381$ & $-1,262$ & $-1,532$ & $-1,765$ & $-1,807$ & $-1,822$ & $-1,696$ \\
$a_{10}$ & 1,313 & 1,174 & 1,263 & 1,010 & 1,799 & 1,716 & 1,832 & 1,837 \\
$a_{11}$ & 2,600 & 3,239 & 2,823 & 3,969 & 3,618 & 4,128 & 3,580 & 3,409 \\
$a_{12}$ & $-3,808$ & $-4,359$ & $-3,968$ & $-4,796$ & $-5,251$ & $-5,718$ & $-5,207$ & $-5,175$ \\
$a_{20}$ & 1,813 & 1,591 & 1,745 & 1,391 & 2,521 & 2,372 & 2,630 & 2,510 \\
$a_{21}$ & 2,508 & 3,475 & 2,819 & 4,287 & 3,130 & 4,067 & 2,848 & 3,081 \\
$a_{22}$ & $-4,247$ & $-5,067$ & $-4,478$ & $-5,505$ & $-5,500$ & $-6,379$ & $-5,267$ & $-5,652$ \\
$a_{30}$ & 1,405 & 1,290 & 1,365 & 1,340 & 1,884 & 2,008 & 1,707 & 1,980 \\
$a_{31}$ & $-0,1397$ & 0,3788 & 0,01968 & 0,2654 & $-0,2700$ & $-1,066$ & 0,6191 & $-0,4049$ \\
$a_{32}$ & $-1,330$ & $-1,776$ & $-1,436$ & $-1,581$ & $-1,694$ & $-0,8829$ & $-2,428$ & $-1,552$ \\
\hline
\end{tabular}


Table 2 - Experimental LCST data

\begin{tabular}{|c|cccc|cccc|}
\hline \multirow{2}{*}{$\begin{array}{c}\text { Oil mass fraction, } \\
\%\end{array}$} & \multicolumn{8}{|c|}{ LCST, ${ }^{\circ} \mathrm{C}$} \\
\cline { 2 - 9 } & ISO 32 & ISO 46 & ISO 68 & ISO 220 & ISO 32 & ISO 46 & ISO 68 & ISO 220 \\
\hline 5 & -51 & -41 & -25 & -15 & - & - & - & - \\
10 & -42 & -35 & -20 & -8 & -36 & -22 & -8 & 1 \\
20 & -37 & -30 & -16 & 1 & -27 & -12 & 0 & 9 \\
30 & -41 & -33 & -19 & 0.5 & -27 & -12 & 2 & 10 \\
40 & -54 & -42 & -29 & -10 & -33 & -19 & -11 & 2 \\
50 & - & -56 & -44 & -25 & -44 & -39 & -32 & -23 \\
\hline
\end{tabular}

Table 3 - The coefficients of equation (2)

\begin{tabular}{|c|cccc|cccc|}
\hline \multirow{2}{*}{ Coefficients } & \multicolumn{4}{|c}{ R407C } & \multicolumn{4}{c|}{ R410A } \\
\cline { 2 - 9 } & ISO 32 & ISO 46 & ISO 68 & ISO 220 & ISO 32 & ISO 46 & ISO 68 & ISO 220 \\
\hline$b_{0}$ & $-59,72$ & $-46,92$ & $-30,78$ & $-24,14$ & $-40,80$ & $-42,00$ & $-28,60$ & $-21,21$ \\
$b_{1}$ & 215,3 & 147,5 & 138,4 & 205,8 & 175,1 & 246,1 & 253,9 & 266,4 \\
$b_{2}$ & $-504,5$ & $-333,2$ & $-331,1$ & $-417,6$ & $-328,6$ & $-478,5$ & $-521,4$ & $-535,7$ \\
\hline
\end{tabular}

Table 4 - The parameters of solubility critical points

\begin{tabular}{|c|cccc|cccc|}
\hline \multirow{2}{*}{ Parameters } & \multicolumn{4}{|c|}{ R407C } & \multicolumn{4}{c|}{ R410A } \\
\cline { 2 - 9 } & ISO 32 & ISO 46 & ISO 68 & ISO 220 & ISO 32 & ISO 46 & ISO 68 & ISO 220 \\
\hline$x, \mathrm{~kg} / \mathrm{kg}$ & 0,213 & 0,221 & 0,209 & 0,246 & 0,266 & 0,257 & 0,243 & 0,249 \\
$t,{ }^{\circ} \mathrm{C}$ & $-36,7$ & $-30,6$ & $-16,3$ & 1,2 & $-17,5$ & $-10,4$ & 2,3 & 11,9 \\
\hline
\end{tabular}

\section{REFERENCES}

1. Geller, V. Z., Davis, K. E. (1995). Solubility and viscosity of refrigerant/POE lubricant mixtures. Proceedings of the $19 \mathrm{~h}$ International Congress of Refrigeration, IVa, Hague, Netherlands, August 1995, 223-229.

2. Geller, V. Z., Bivens D. B., Yokozeki A. (1995). Solubility and viscosity of alternative refrigerant/lubricant oil mixtures. Proceedings of the 1995 International CFC and Halon Alternative Conference, Washington, DC, November 1995, 59-67.

3. Burton, C.M., Jacobi, A.M., Mehendale, S.S. (1999). Vapour-liquid equilibrium for R32 and R410A mixed with a polyol ester: non-ideality and local composition modeling. International Journal of Refrigeration, No. 22, 458-471. 7007(99)00012-2

4. Lapardin, N.I. (2010). Saturated pressure and viscosity of mixture of refrigerant R407C with lubricant ISO 46. Pischevaya nauka i tekhnolohiya [Food science and technology], No. 4 (13), 66-58 (in Russian)
5. Wang Qin, Xu Ying-jie, Chen Xi, Gao Zan-jun, Han Shuai, Han Xiao-hong, Chen Guang-ming (2010). Experimental studies on a mixture of HFC-32/125/161 as an alternative refrigerant to HCFC-22 in the presence of polyol ester. Fluid Phase Equilibria, 293(1), 110-116. DOI: http://dx.doi.org/10.1016/j.fluid.2010.02.033

6. Bobbo, S., Fedele, L., Pernechele, F., Stryjek, R. (2008). Solubility of CO2 in Commercial POE Oils with Different Standard Viscosity. Proceedings of the International Refrigeration and Air Conditioning Conference at Purdue, July 14-17, 2008, 2373, 1-8.

7. Zhidkov, V. V. (1997). Ecology and energy analysis of household refrigeration appliances on alternative refrigerants: dys. kand. tekhn. nauk. Odessa, 199 p. (in Russian)

8. Semenyuk, Yu. V., Nichenko, S. V., Lozovsky, T. L., Zhelezny, V. P. (2009). Study of selective solubility of refrigerant mixtures in compressor oils. Themat. zb. nauk. pr. [Thematic collection of scientific works]. Donetsk, DonNUET, Vol. 21, 27 - 34 (in Russian) 


\section{В. З. Геллер, Н. І. Лапардін}

Одеська національна академія харчових технологій, вул. Канатна 112, Одеса, 65039, Україна

\section{РОЗЧИННІСТЬ I ЗМІШУВАНІСТЬ ХОЛОДОАГЕНТІВ R407C I R410А 3 СИНТЕТИЧНИМИ КОМПРЕСОРНИМИ МАСЛАМИ}

У статті наведені експериментальні дані про розчинність та низькотемпературну змішуваність холодоагентів R407C $i$ R410A у чотирьох різних комериійних поліолефірних (РОE) маслах, виробництва однієї $i$ тієї ж компанії, але з різною стандартною в'язкістю. Мета роботи оцінити можливу кореляцію розчинності та змішуваності зі стандартною в'язкістю поліолефірного масла. Тиск парів (розчинність) вимірювалася методом постійного об'єму при масових концентраціях масла 30, 50, 70, 80 i 90\% в діапазоні температур від -20 до $+100{ }^{\circ} \mathrm{C} i$ тиску до 5 МПа. Вимірювання низькотемпературної змішуваності - верхньої критичної температури розчинення (ВКТР) - були зроблені з використанням сапфірової комірки високого тиску. ВКТР безпосередньо отримані візуальним спостереженням «молочного помутніння» 3 подальшим розділенням фаз. Дані про змішуваність були отримані для масових часток масла від 5 до 50\% в діапазоні температур від -60 до $0{ }^{\circ} \mathrm{C}$. Набір простих рівнянь був отриманий для опису експериментальних результатів. Аналіз отриманих даних показав, щзо розчинність сумішей холодоагент/масло слабо залежить від стандартної в'язкості масла. У той же час, зона незмішуваності набагато більше відрізняється для різних сумішей холодоагент/масло. Чим менше стандартна в'язкість масла, тим менше ВКТР суміші холодоагент/масло. ВКТР для сумішей R407C з маслами ISO 32 і ISO 220 відрізняються на 30-45 ${ }^{\circ} \mathrm{C}$.

Ключові слова: Розчинність; Змішуваність; Холодоагент; Поліолефірне масло; Суміш Холодоагент/Масло; Вимірювання; Рівняння. 